\title{
Penentuan Desa Wisata Terbaik di Kabupaten Tabanan dengan Model AHP dan BORDA
}

\author{
Putu Sugiartawan*¹, Paholo Iman Prakoso ${ }^{2}$, I Made Gitra Aryawan ${ }^{3}$ \\ ${ }^{1}$ Program Studi Teknik Informatika, STMIK STIKOM Indonesia, Bali \\ ${ }^{2}$ Information Technology, Computer and Sciences Association (INFOTEKS) \\ ${ }^{3}$ Fakultas Ekonomi, Ekonomi Pembangunan, Universitas Tabanan, Bali \\ e-mail: *1putu.sugiartawan@mail.ugm.ac.id, ${ }^{2}$ pahalaimanprakoso@gmail.com, \\ 33ade.gitra11@gmail.com
}

\begin{abstract}
Abstrak
Kabupaten Tabanan, sedang menggalakan pengembangan desa wisata dan pembangunan banyak desa wisata yang ada di daerah. Pengembangan desa wisata dapat menghasilkan PAD atau pendapatan daerah yang besar yang diperoleh dari sektor pariwisata. Permasalahan yang ada adalah tidak semua desa wisata berkembang dan menghasilkan pendapatan bagi pemerintah, bahkan banyak desa wisata yang sepi dari kunjungan wisatawan. Pemilihan desa wisata terbaik bertujuan untuk mengetahui faktor-faktor pendukung apa saja yang dapat meningkatkan kunjungan wisatawan serta memberikan bantuan kepada desa wisata tersebut. Tujuan pemberi bantuan tersebut adalah untuk meningkatkan kualitas dari pariwisata di daerah tersebut. Model yang digunakan dalam pemilihan desa wisata adalah model AHP dan BORDA. Kedua model tersebut mampu meranking desa wisata dari beberapa kreteria yang dimiliki desa wisata. Adapun pemegang keputusan pada system ini adalah Dinas Pariwisata Kabupaten Tabanan dan Provinsi Bali.
\end{abstract}

Kata kunci-AHP, BORDA, desa wisata, kabupaten tabanan, perankingan

\begin{abstract}
Tabanan Regency, is promoting the development of tourist villages and the development of many tourist villages in the area. The development of tourism villages can generate large regional income or income derived from the tourism sector. The problem is that not all tourist villages develop and generate revenue for the government, even many tourist villages are quiet from tourist visits. The selection of the best tourism village aims to find out what supporting factors can increase tourist visits and provide assistance to the tourist village. The purpose of the aid providers is to improve the quality of tourism in the area. The model used in the selection of tourist villages is the AHP and BORDA models. Both models are able to rank tourist villages from several criteria owned by tourist villages. The decision holder in this system is the Tourism Office of Tabanan Regency and the Province of Bali.
\end{abstract}

Keywords-AHP, BORDA, tourist village, Tabanan regency, ranking 


\section{PENDAHULUAN}

Indonesia memiliki banyak objek-objek wisata dan desa wisata yang menarik untuk dikunjungi dan tersebar di seluruh provinsi yang ada di Indonesia. Bali yang merupakan salah satu barometer pariwisata dan tujuan wisatawan mancanegara, yang ditunjukan dari hampir sebagian jumlah wisatwan berkunjung ke Bali [1] [2]. Pariwisata menjadi salah satu sektor penting dalam pendulang devisa, ini dibuktikan dengan dengan dihasilkannya devisa yang besar dari sektor pariwisata. Namun demikian, jumlah wisatawan mancanegara yang berkunjung ke objek wisata di Indonesia masih lebih rendah dibandingkan dengan negaranegara lain di kawasan ASIA seperti Korea, Jepang, Singapura dan Cina. Dalam rangka meningkatkan kunjungan wisata, pemerintah tidak hanya berpatokan obyek wisata yang sudah ada dan tersebar di setiap kabupaten yang ada di Bali. Peningkatan desa wisata menjadi tolak ukur pengembangan pariwisata yang ada di Bali, disamping dapat diperuntukan sebagai obyek wisata namun desa wisata tersebut secara langsung dapat meningkatkan pendapatan masyarakat desa setempat.

Saat ini pemerintah Kabupaten Tabanan, sedang menggalakan pengembangan desa wisata dan pembangunan banyak desa wisata yang ada di daerah. Berkaca kepada PAD yang besar yang diperoleh dari sektor pariwisata, pemerintah Kabupaten Tabanan secara berkesinambungan mengalokasikan pendapatannya pada sektor pariwisata khususnya pengembangan Desa Wisata. Desa wisata merupakan objek wisata berbasis kemasyarakatan, di daerah tabanan tercatat terdapat 27 desa wisata pada Tahun 2018 (Dispar Pemda Tabanan). Bahkan Tabanan tidak tanggung-tanggung menargetkan akan mengembangkan desa wisata sebanyak 133 desa wisata. Dengan adanya desa wisata ini diharapkan akan mampu meningkatkan kunjungan wisatawan ke kabupaten Tabanan, tentunya berdampak dengan kesejahteraan masyarakatnya yang akan meningkat. Dari 27 desa wisata yang ada di Kabupaten Tabanan, terdapat enam desa wisata yang sudah terkenal dan banyak dikunjungi oleh wisatawan. Adapun ke enam desa wisata tersebut diantaranya Desa Mengesta, Desa Salak, Desa Tista, Desa Pinge, Desa Nyambu dan Desa Jati Luwih. Dari ke enam desa wisata tersebut selanjutnya akan di pilih desa wisata yang selanjutnya memperoleh bantuan dan penyuluhan lebih intens dari Dinas Pariwisata Provinsi Bali. Tujuan dari pemilihan desa wisata tersebut adalah untuk menjadi pedoman untuk desa wisata lainnya di daerah Bali.

Pemilihan desa wisata terbaik dilakukan oleh Dinas Pariwisata Kabupaten Tabanan dan Dinas Pariwisata Provinsi Bali. Masing-masing pemegang keputusan memiliki kreteria-kriteria, penilaian dan pembobotan yang berbeda satu dengan yang lainnya. Pemilihan obyek wisata masing-masing pemegang keputusan dilakukan dengan menggunakan model Analytical Hierarchy Process (Analytical Hierarchy Process). Metode AHP didasarkan atas tiga prinsip dasar, yaitu penyusunan hirarki, penentuan prioritas dan konsistensi logis. Menurut [3], metode AHP dapat dipakai untuk memecahkan masalah yang kompleks, dengan parameter atau kriteria yang dipertimbangkan cukup banyak. Metode AHP pada pemilihan desa wisata ini digunakan untuk melakukan pembobotan parameter yang digunakan dalam pengambilan keputusan. Model AHP menghasilkan nilai hasi perankingan individu masing-masing pemegang keputusan, sehingga diperlukan sebuah model untuk menggabungkan hasil keputusan tersebut. Model BORDA dapat digunakan untuk menghasilkan sebuah keputusan dari beberapa keputusan yang telah di putuskan. Metode BORDA mampu mengakomodir proses evaluasi analisa dan pemilihan desa wisata secara kelompok berdasarkan penilai masing-masing Pemegang keputusan atau decision support (DM) [4], [5]. Pada penelitian ini terdapat kriteria yang berbeda antara DM Pemerintah Kabupaten Tabanan dengan DM Dinas Pariwisata Bali. Masing-masing kreteria tersebut mewakili penilaian masing-masing DM terhadap alternatif desa wisata.

JSIKTI Vol. 2, No. 1, September 2019: $43-52$ 
Berdasarkan beberapa permasalahan diatas, maka topik yang diajukan pada penelitian ini adalah Penentuan Desa Wisata Terbaik di Kabupaten Tabanan dengan Model Analytical Hierarchy Process (AHP) dan BORDA. Fokus pada penelitian ini adalah penentuan bobot oleh masing-masing DM dan penentuan kreteria spesifik yang diberikan oleh masing-masing DM. Pada model AHP terdapat skala pengukuran dan metode untuk mendapatkan prioritas dan empertimbangkan konsistensi logis dalam penilaian yang digunakan untuk menentukan prioritas [6].

\section{METODE PENELITIAN}

Metode penelitian meliputi analisa permasalahan, arsitektur atau rancangan metode yang digunakan untuk menyelesaikan masalah pada penelitian.

\subsection{Desa Wisata}

Desa Wisata adalah sebuah area atau daerah pedesaan yang memiliki daya tarik khusus yang dapat menajadi daerah tujuan wisata. Di desa wisata, penduduk masih memegang tradisi dan budaya yang masih asli. Serta beberapa aktivitas pendukung seperti sistem bertani, berkebun serta makanan traditional juga berkontribusi mewarnai keberadaan desa wisata itu sendiri. Selain faktor tersebut, faktor lingkunganiyang masih asli dan terjaga merupakan faktoripenting yang harus ada disuatu desa wisata [10-11]. Menurut Peraturan Kementrian Kebudayaan dan Pariwisata, desa wisata adalah suatu bentuk kesatuan antara akomodasi, atraksi, sarana dan prasarana pendukung wisata yang disajikan dalam suatu tatanan kehidupan masyarakat yang menyatu dengan tradisi yang berlaku.

\section{1.1 Pengertian pariwisata}

Pariwisata merupakan suatu aktivitas dari yang dilakukan oleh wisatawan domestik maupun mancanegara ke suatu tempat tujuan wisata di luar keseharian dan lingkungan tempat tinggal untuk melakukan persinggahan sementara, yang didorong beberapa keperluan tanpa bermaksud untuk mencari nafkah dan namun didasarkan atas kebutuhan untuk mendapatkan kesenangan, dan disertai untuk menikmati berbagai hiburan yang dapat melepaskan lelah dan menghasilkan suatu pengalaman liburan dan layanan hospitality [7]-[12].

\section{1.2 Komponen desa wisata}

Komponen utama dari Desa Wisata terdiri dari dua komponen utama [11], yang diantaranya ;

1. Pertama yaitu akomodasi yang digunakan sebagai tempat tinggal wisatawan, yang memanfaatkan tempat tinggal masyarakat lokal setempat dan ruang yang dikembangkan di area sekitar desa wisata.

2. Kedua yaitu atraksi atau daya tarik, daya tarik desa wisata berupa kehidupan keseharian penduduk setempat beserta kondisi lingkungan khas pedesaan.

Adapun kajian komponen desa wisata dari beberapa sumber lainnya, dijabarkan pada Tabel 1. Terdapat beberapa komponen yang berbeda dalam setiap kajian, dan masing-masing komponen merepresentasikan dari pengembangan dan peningkatan desa wisata. 
Tabel 1 Kajian desa wisata

\begin{tabular}{|l|l|l|}
\hline No & Sumber teori & Komponen Desa Wisata \\
\hline 1 & Gumelar (2010) & 1. Keunikan, keaslian, sifat khas \\
& & $\begin{array}{l}\text { 2. Letaknya berdekatan dengan daerah alam } \\
\text { 3. Berkaitan dengan kelompok atau masyarakat berbudaya } \\
\text { yang secara hakiki dan menarik minat pengunjung } \\
\text { 4. Memiliki peluang untuk berkembang baik dari sisi } \\
\text { prasarana dasar, maupun sarana lainnya. }\end{array}$ \\
& & $\begin{array}{l}\text { 1. Partisipasi masyarakat lokal } \\
\text { 2. Sistem norma setempat }\end{array}$ \\
\hline 2 & Prasiasa (2011) & $\begin{array}{l}\text { 3. Sistem adat setempat } \\
\text { 4. Budaya setempat }\end{array}$ \\
\hline 3 & Zakaria (2014) & $\begin{array}{l}\text { 1. partisipasi masyarakat lokal } \\
\text { 2. sistem norma yang ada di desa tersebut }\end{array}$ \\
& & $\begin{array}{l}\text { 3. adat } \\
\text { 4. budaya setempat yang masih asli }\end{array}$ \\
\hline 4 & Zebua (2016) & $\begin{array}{l}\text { 1. Akomodasi } \\
\text { 2. Atraksi atau daya tarik }\end{array}$ \\
\hline 5 & Dinas Pariwisata & $\begin{array}{l}\text { 1. Memiliki potensi yang unik dan khas } \\
\text { 2. Memiliki adat istiadat dan tradisi budaya, seni kerajinan } \\
\text { dan kesenian tradisional }\end{array}$ \\
& (2014) & $\begin{array}{l}\text { 3. Memiliki fasilitas pendukung, seperti } \\
\text { akomodasi/penginapan, serta ruang khusus untuk } \\
\text { wisatawan berinteraksi langsung dengan masyarakat } \\
\text { sekitar }\end{array}$ \\
\hline
\end{tabular}

\subsection{Analytical Hierarchy Process (AHP)}

Metode Analytical Hierarchy Process (AHP) adalah metode pengambilan keputusan multi kriteria yang dapat mengkombinasikan analisis kualitatif dan analisis kuantitatif [7][13]. Sedangkan menurut [8] metode AHP adalah metode yang dapat menyelesaikan masalah multi kriteria yang kompleks. Metode AHP digunakan oleh pengambil keputusan untuk memberikan penilaian kepentingan relatif setiap kriteria, kemudian menentukan nilai preferensi setiap alternatif keputusan berdasarkan kriteria masing-masing. Metode AHP dapat melakukan proses identifikasi yang lebih baik, lebih mudah, lebih efisien dalam analisis bobot kriteria dan alternatif.

Metode AHP memungkinkan melakukan menggabungan logika untuk suatu data yang bersifat kuantitatif, kualitatif, pengalaman, wawasan, intuisi serta dapat diimplementasikan kedalam suatu algoritma. Dengan demikian, memungkinkan para pengambil keputusan untuk menemukan bobot masing-masing kriteria dan tingkat perbandingan alternatif [14][16]. berikut:

Menurut [8] tahapan dalam pemecahan masalah menggunakan metode AHP sebagai

1. Membentuk struktur hiraki

Struktur hiraki merupakan gambaran umum dalam penentuan masalah dan solusi. Implementasi penyusunan striktur hiraki dapat dilihat pada Gambar 3.11.

2. Membuat matriks perbandingan

Matriks perbandingan merupakan matriks persegi $A=\left(a_{i j}\right)_{n x n}$ yang meliputi: $a_{i j}>0$, $\mathrm{a}_{\mathrm{ij}}=1 / \mathrm{a}_{\mathrm{ji}}$ dan $\mathrm{a}_{\mathrm{ii}}=\mathrm{a}_{\mathrm{jj}}=1$, dimana sering disebut dengan matriks reciprocal. 


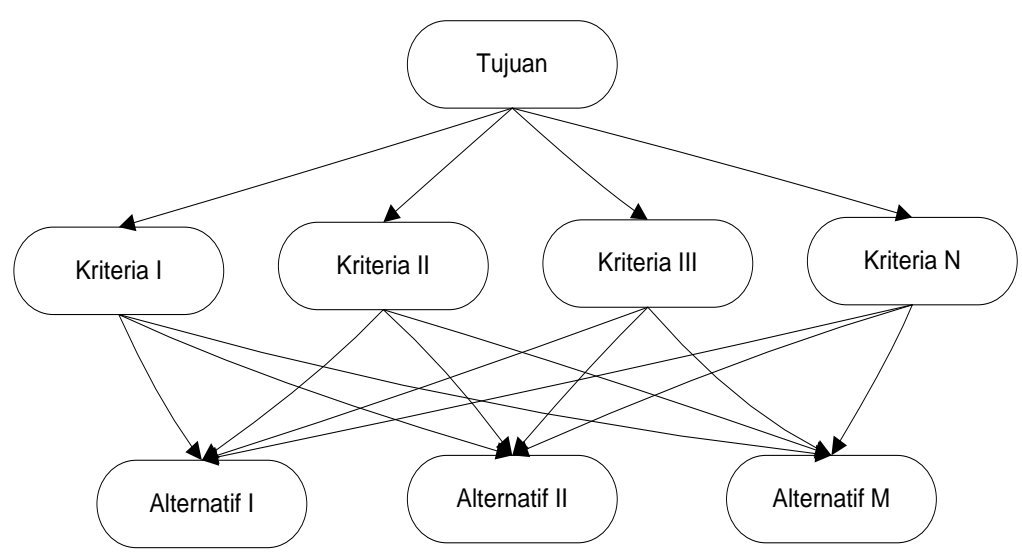

Gambar 1 struktur hirarki AHP, Meng (2013)

Tabel 2 Skala nilai perbandingan

\begin{tabular}{|c|c|c|}
\hline $\begin{array}{c}\text { Tingkat } \\
\text { Kepentingan }\end{array}$ & Definisi & Keterangan \\
\hline 1 & Sama pentingnya & $\begin{array}{l}\text { Kedua elemen mempunyai pengaruh yang } \\
\text { sama. }\end{array}$ \\
\hline 3 & $\begin{array}{l}\text { Agak lebih penting } \\
\text { yang satu atas } \\
\text { lainnya }\end{array}$ & $\begin{array}{l}\text { Pengalaman dan penilaian sangat } \\
\text { memihak satu elemen dibandingkan } \\
\text { dengan pasangannya. }\end{array}$ \\
\hline 5 & Cukup penting & $\begin{array}{l}\text { Pengalaman dan keputusan menunjukkan } \\
\text { kesukaan atas satu aktifitas lebih dari } \\
\text { yang lain. }\end{array}$ \\
\hline 7 & Sangat penting & $\begin{array}{l}\text { Pengalaman dan keputusan menunjukkan } \\
\text { kesukaan yang kuat atas satu aktifitas } \\
\text { lebih dari yang lain. }\end{array}$ \\
\hline 9 & $\begin{array}{l}\text { Mutlak lebih } \\
\text { penting }\end{array}$ & $\begin{array}{l}\text { Satu elemen mutlak lebih disukai } \\
\text { dibandingkan dengan pasangannya, pada } \\
\text { tingkat keyakinan tertinggi. }\end{array}$ \\
\hline $2,4,6,8$ & $\begin{array}{l}\text { Nilai tengah } \\
\text { diantara dua nilai } \\
\text { berdekatan }\end{array}$ & Bila kompromi dibutuhkan. \\
\hline
\end{tabular}

Nilai skala perbandingan yang digunakan sebagai masukan data dapat dilihat pada Tabel 3.1.

3. Menghitung hasil perkalian masing-masing elemen pada setiap baris $M i$, sesuai dengan persamaan berikut ;

$$
M i=\prod_{j=1}^{n} a_{i j}
$$

4. Menghitung $\mathrm{n}$ akar pangkat dari $M i$ menggunakan berikut ;

$$
\overline{W_{l}}=\sqrt[n]{M i}
$$

5. Jumlah vector $W i=(\overline{W 1}, \overline{W 2}, \ldots, \overline{W n})^{t}$, untuk proses normalisasi dapat dilihat pada persamaan berikut ;

$$
W i=\frac{\overline{W_{u}}}{\sum_{j=1}^{n} \bar{W}_{l}}
$$

Dengan demikian, nilai $\mathrm{W}=\left(\mathrm{W}^{1}, \mathrm{~W}^{2}, \mathrm{~W}^{3}, \ldots, \mathrm{W}^{\mathrm{n}}\right)^{\mathrm{t}}$ merupakan fitur dari vector matriks. 
6. Menurut Saaty (2007) menghitung nilai lamdamax dari matriks dapat dilihat pada persamaan berikut ;

$$
\lambda \max =\sum_{i=1}^{n} \sum_{j}^{n} a_{i j} W_{j}
$$

7. Tes konsistensi

Proses perhitungan nilai consistency indeks (CI) dapat dilihat pada persamaan berikut ;

$$
\mathrm{CI}=\frac{(\lambda \text { maks }-\mathrm{n})}{(\mathrm{n}-1)}
$$

8. Menghitung consistency ratio $(\mathrm{CR})$ dapat dilihat pada persamaan berikut ;

$$
\mathrm{CR}=\frac{\mathrm{CI}}{\mathrm{RI}}
$$

Untuk memperoleh nilai random consistency index (RI) dapat dilihat pada Tabel 3.

Tabel 3 Indeks random konsistensi

\begin{tabular}{|c|c|c|c|c|c|c|c|c|c|}
\hline $\mathrm{N}$ & 1 & 2 & 3 & 4 & 5 & 6 & 7 & 8 & 9 \\
\hline $\mathrm{RI}$ & 0.00 & 0.00 & 0.58 & 0.90 & 1.12 & 1.24 & 1.32 & 1.41 & 1.45 \\
\hline
\end{tabular}

Berdasarkan hasil dari consistency ratio $(\mathrm{CR})$ yang diperoleh, dengan nilai $\mathrm{CR}<0.1$ maka dapat dinyatakan konsisten.

\section{3 BORDA}

Metode Borda merupakan metode voting yang dapat menyelesaikan pengambilan keputusan kelompok, dimana dalam penerapannya masing-masing decision maker memberikan peringkat berdasarkan alternatif pilihan yang ada, proses pemilihan dalam metode Borda, masing-masing voter diberikan alternatif pilihan. Di misalkan ada $n$ kandidat pilihan, kandidat atau alternatif pertama

diberikan $n$ poin oleh voter atau decision maker. Kandidat kedua diberikan poin n-1 dan seterusnnya. Penentuan pemenang atau alternatif terbaik berdasarkan poin yang tertinggi. Alternatif dengan nilai tertinggi merupakan bahan pertimbangan yang akan dipilih [16-17]

Menurut [12-14]tahapan dan proses perhitungan metode AHP hybrid dengan metode Borda berdasarkan analisa multi decision maker, meliputi:

1. Masing-masing decision maker menerapkan konsep perhitungan AHP. Setiap decision maker melakukan proses perbandingan berpasangan kriteria dan evaluasi alternatif, sehingga menghasilkan bobot dan ranking individu masing-masing alternatif.

2. Setelah bobot AHP setiap alternatif telah ditentukan, proses selanjutnya melakukan evaluasi ranking dengan menggunakan metode Borda. Penentuan ranking alternatif diperoleh dari nilai bobot dalam proses.

3. Jumlahkan masing-masing skor setiap alternatif

\section{HASIL DAN PEMBAHASAN}

Pada bagian ini terdiri dari beberapa tahap penyelesain dengan model AHP dan BORDA pada penentuan desa wisata terbaik di daerah Tabanan.

\subsection{Alternatif, kreteria dan DM}

Adapun alternatif, kriteria dan decision maker dijabarkan pada penjelasan berikut. Alternatif dari masing-masing desa wisata terdiri dari 6 alternatif, dijabarkan pada Tabel 4.

JSIKTI Vol. 2, No. 1, September 2019: $43-52$ 
Tabel 4 Alternatif desa wisata

\begin{tabular}{|l|l|}
\hline Kode & Alternatif \\
\hline A1 & Desa Mengesta \\
\hline A2 & Desa Salak \\
\hline A3 & Desa Tista \\
\hline A4 & Desa Pinge \\
\hline A5 & Desa Nyambu \\
\hline A6 & Desa Jati Luwih \\
\hline
\end{tabular}

Alternatif desa wisata memiliki kriteria yang berbeda antara DM Dinas Pariwisata Provinsi Bali dengan DM Pemerintah Kabupaten Tabanan. Masing-masing kriteria dijabarkan pada Tabel 2 dan Tabel 3. Penilai yang diberikan DM kepada masing-masing alternatif memiliki perbedaan, tergantung nilai yang diberikan.

Tabel 5 Kreteria DM Dinas Pariwisata Provinsi Bali

\begin{tabular}{|l|l|l|}
\hline Kode & Alternatif & Keterangan \\
\hline C1 & Potensi fisik lingkungan alam & $\begin{array}{l}\text { persawahan, bentang alam, tata lingkungan } \\
\text { perkampungan yang unik dan khas. }\end{array}$ \\
\hline C2 & $\begin{array}{l}\text { Potensi kehidupan sosial budaya } \\
\text { masyarakat }\end{array}$ & $\begin{array}{l}\text { pola kehidupan keseharian masyarakat yang unik dan } \\
\text { khas, adat istiadat dan tradisi budaya }\end{array}$ \\
\hline C3 & $\begin{array}{l}\text { Tingkat penerimaan dan } \\
\text { komitmen masyarakat }\end{array}$ & $\begin{array}{l}\text { Adanya sikap keterbukaan dan penerimaanmasayarakat } \\
\text { setempat terhadap kegiatanpariwisata sebagai bentuk } \\
\text { kegiatan yang akanmenciptakan interaksi antar } \\
\text { masyarakat lokaldengan wisatawan }\end{array}$ \\
\hline C4 & $\begin{array}{l}\text { Ketersediaan sumber daya } \\
\text { manusia lokal }\end{array}$ & $\begin{array}{l}\text { Ketersediaan sumber daya manusia lokal } \\
\text { dalammengelola desa wisata, baik sebagai pemandu, } \\
\text { penyedia transportasi, bahkan pengelola desawisata }\end{array}$ \\
\hline C5 & $\begin{array}{l}\text { Sistem kepercayaan dan } \\
\text { kemasyarakatan }\end{array}$ & $\begin{array}{l}\text { Mengenai aturan-aturan yang khusus pada komunitas } \\
\text { sebuah desa }\end{array}$ \\
\hline
\end{tabular}

Penilaian yang diberikan DM kepada masing-masing alternatif memiliki perbedaan, tergantung nilai yang diberikan. Adapun DM Pemerintah Pemda Tabanan memiliki kreteria lebih banyak dibandingkan DM Dinas Pariwisata Provinsi Bali.

Tabel 6 Kreteria DM Pemerintah Kabupaten Tabanan

\begin{tabular}{|c|c|c|}
\hline Kode & Alternatif & Keterangan \\
\hline $\mathrm{C} 1$ & $\begin{array}{l}\text { Sarana dan prasarana yang } \\
\text { memadai }\end{array}$ & $\begin{array}{l}\text { Sarana dan prasarana di obyek wisata seperti toilet, ATM } \\
\text { dan lain-lain }\end{array}$ \\
\hline $\mathrm{C} 2$ & Layanan pegawai pemda & terdapat layanan pegawai pemda untuk obyek wisata \\
\hline $\mathrm{C} 3$ & $\begin{array}{l}\text { Keterampilan masyarakat } \\
\text { dalam berbahasa asing yang } \\
\text { fasih }\end{array}$ & Keterampilan masyarakat sekitar berbahasa asing \\
\hline $\mathrm{C} 4$ & $\begin{array}{l}\text { Manajemen pengelolaan } \\
\text { objek }\end{array}$ & Pengelolaan desa wisata \\
\hline C5 & Kebersihan lingkungan & kebersihan lingkungan desa wisata \\
\hline C6 & $\begin{array}{l}\text { Pemanfaatan SDM sebagai } \\
\text { pemandu wisata }\end{array}$ & masyarakat mampu sebagai pemandu obyek wisata \\
\hline $\mathrm{C} 7$ & Penataan lingkungan & penataan lingkungan yang baik di desa wisata \\
\hline
\end{tabular}

Detail masing-masing DM dijabarkan pada Tabel 7, terdapat dua buah DM yang akan menilai setiap desa wisata. DM 1 merupakan Dinas Pariwisata Provinsi Bali, yang diwakilkan oleh bagian pengembangan obyek wisata dan desa wisata. DM 2 adalah dari Pemda Kabupaten Tabanan yang diwakilkan oleh Dinas Pariwisata.

Tabel 7 Penentu pemilihan obyek wisata

\begin{tabular}{|l|l|}
\hline Kode & Keterangan \\
\hline DM 1 & Dinas Pariwisata Provinsi Bali \\
\hline DM 2 & Dinas Pemda Kabupaten Tabanan \\
\hline
\end{tabular}




\subsection{Penentuan Ranking Individu}

Proses perhitungan penentuan obyek wisata terbaik, diawali dengan perbandingan masing-masing kriteria. Adapun perbandingan kriteria untuk DM 1 dijabarkan pada Tabel 8, perbandingan kriteria ini bertujuan untuk mencari bobot masing-masing kriteria.

Tabel 8 Penentu pemilihan obyek wisata

\begin{tabular}{|c|c|c|c|c|c|}
\hline & $\mathrm{C}_{1}$ & $\mathrm{C}_{2}$ & $\mathrm{C}_{3}$ & $\mathrm{C}_{4}$ & $\mathrm{C}_{5}$ \\
\hline $\mathrm{C}_{1}$ & 1 & 2 & 1 & 4 & 1 \\
\hline $\mathrm{C}_{2}$ & 0,5 & 1 & 0,5 & 1 & 2 \\
\hline $\mathrm{C}_{3}$ & 1 & 2 & 1 & 3 & 2 \\
\hline $\mathrm{C}_{4}$ & 0,25 & 1 & 0,3333 & 1 & 1 \\
\hline $\mathrm{C}_{5}$ & 1 & 0,5 & 0,5 & 1 & 1 \\
\hline SUM & 3,75 & 6,5 & 3,3333 & 10 & 7 \\
\hline
\end{tabular}

Tabel 9 Penentu pemilihan obyek wisata

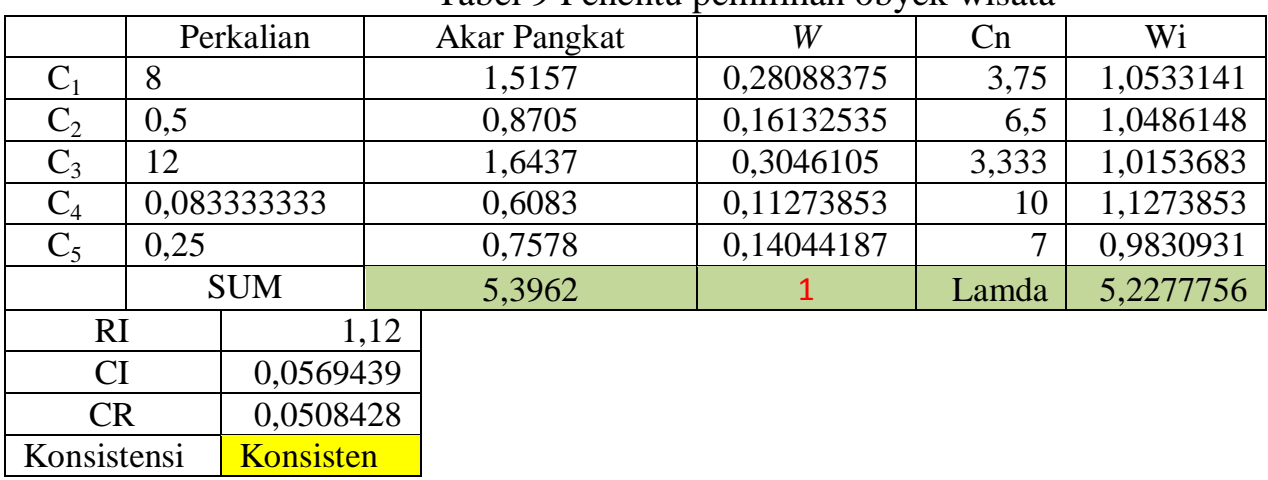

Proses selanjutnya adalah untuk mencari nilai dari CR (Consistency Ratio) dari proses penentuan nilai bobot masing-masing. Jika nilai CR lebih besar atau sama dengan 1 maka nilai tersebut dinyatakan tidak konsisten dan proses perbandingan kriteria mesti di ulangi lagi, sampai dengan nilai CR kurang dari 1. Pada Tabel 9 menunjukan nilai CR kurang dari satu sehingga bobot nilai tersebut konsisten dan bobot hasil perhitungan ditunjukan pada Tabel 10 .

Tabel 10 Bobot kriteria DM 1 dan Bobot kriteria DM 2

\begin{tabular}{|l|r|}
\hline Kriteria & \multicolumn{2}{|l|}{ Bobot } \\
\hline C1 & 0,280884 \\
\hline C2 & 0,161325 \\
\hline C3 & 0,30461 \\
\hline C4 & 0,112739 \\
\hline C5 & 0,140442 \\
\hline
\end{tabular}

\begin{tabular}{|l|l|l|l|}
\hline Kode & Bobot & RI & 1,32 \\
\hline C1 & 0,253448 & CI & 0,065272 \\
\hline C2 & 0,110979 & CR & 0,049448 \\
\hline C3 & 0,211065 & Konsistensi & Konsisten \\
\hline C4 & 0,117597 & \multicolumn{1}{|}{} \\
\cline { 1 - 2 } C5 & 0,110979 & \multirow{2}{*}{} \\
\cline { 1 - 2 } C6 & 0,13758 & \multicolumn{1}{|}{} \\
\cline { 1 - 2 } C7 & 0,058353 & &
\end{tabular}

Pada Tabel 10 dijabarkan bobot masing-masing DM, nilai bobot pada DM 1 tertinggi dimiliki oleh kriteria potensi fisik lingkungan, yang terdiri dari persawahan, bentang alam, tata lingkungan perkampungan yang unik dan khas. Bobot untuk DM 2, nilai tertinggi dimiliki oleh sarana dan prasarana yang memadai meliputi Toilet, ATM, Toko oleh-oleh, jaringan telekomunikasi dan lain-lain. Setelah diperoleh nilai bobot, selanjutnya di tentukan ranking dari masing-masing DM.

Proses perankingan individu di dapat dari hasil penilaian DM terhadap masing-masing alternatif, dan selanjutnya nilai tersebut dikalikan dengan bobot dari setiap kriteria. Dari perhitungan tersebut maka diperoleh nilai akhir, nilai tertinggi akan memperoleh ranking pertama dan nilai terendah akan memperoleh ranking terakhir. Pada Tabel 11 menunjukan hasil perankingan individu dari DM Dinas Provinsi Bali. 
Tabel 11 Ranking individu DM 1

\begin{tabular}{|c|c|c|c|c|c|c|c|}
\hline Kode & $\mathrm{C}_{1}$ & $\mathrm{C}_{2}$ & $\mathrm{C}_{3}$ & $\mathrm{C}_{4}$ & $\mathrm{C}_{5}$ & & \\
\hline bobot & 0,280884 & 0,161325 & 0,30461 & 0,112739 & 0,140442 & Jumlah & Ranking \\
\hline $\mathrm{A} 1$ & 0,195406 & 0,065334791 & 0,084792395 & 0,125432 & 0,133039804 & 0,124081 & 5 \\
\hline A2 & 0,219336 & 0,174258881 & 0,16777044 & 0,160833 & 0,156666588 & 0,18096 & 3 \\
\hline A3 & 0,182637 & 0,138309365 & 0,211377509 & 0,193151 & 0,188146695 & 0,1862 & 2 \\
\hline A4 & 0,135487 & 0,127021371 & 0,146864736 & 0,104445 & 0,101738796 & 0,129348 & 4 \\
\hline A5 & 0,152079 & 0,085435724 & 0,082254568 & 0,101319 & 0,082180638 & 0,104519 & 6 \\
\hline A6 & 0,115054 & 0,409639868 & 0,306940353 & 0,314821 & 0,33822748 & 0,274893 & 1 \\
\hline
\end{tabular}

Pada Tabel 12 menunjukan hasil perankingan Pemda Kabupaten Tabanan, ranking pertama di miliki oleh desa wisata Jati Luwih dan peringakt kedua serta ketiga dimiliki oleh desa tista dan desa salak. Ranking tersebut sama dengan yang diperoleh oleh DM 1.

Tabel 12 Ranking individu DM 2

\begin{tabular}{|l|c|c|c|c|c|c|c|c|c|}
\hline Kode & $\mathrm{C}_{1}$ & $\mathrm{C}_{2}$ & $\mathrm{C}_{3}$ & $\mathrm{C}_{4}$ & $\mathrm{C}_{5}$ & $\mathrm{C}_{6}$ & $\mathrm{C}_{7}$ & \multirow{2}{*}{ Jumlah } & \multirow{2}{*}{ Ranking } \\
\hline bobot & 0,2534 & 0,1110 & 0,2111 & 0,1176 & 0,1110 & 0,1376 & 0,0584 & & \\
\hline A1 & 0,1954 & 0,0653 & 0,0848 & 0,1254 & 0,1330 & 0,1600 & 0,2069 & 0,138278 & 4 \\
\hline A2 & 0,2193 & 0,1743 & 0,1678 & 0,1608 & 0,1567 & 0,1245 & 0,1610 & 0,173171 & 3 \\
\hline A3 & 0,1826 & 0,1383 & 0,2114 & 0,1932 & 0,1881 & 0,1884 & 0,1535 & 0,18473 & 2 \\
\hline A4 & 0,1355 & 0,1270 & 0,1469 & 0,1044 & 0,1017 & 0,1019 & 0,1046 & 0,123128 & 5 \\
\hline A5 & 0,1521 & 0,0854 & 0,0823 & 0,1013 & 0,0822 & 0,0864 & 0,0845 & 0,103231 & 6 \\
\hline A6 & 0,1151 & 0,4096 & 0,3069 & 0,3148 & 0,3382 & 0,3388 & 0,2895 & 0,277463 & 1 \\
\hline
\end{tabular}

\subsection{Perankingan Kelompok dengan BORDA}

Proses terakhir dari pemilihan obyek wisata ini adalah dengan menggabungkan keputusan dari masing-masing DM. Penggabungan keputusan ini menggunakan teknik model BORDA. Pada model ini akan memberikan poin kepada ranking terkecil dengan poin terbesar, dan selanjutnya dijumlahkan sehingga memperoleh hasil akhir. Nilai tertinggi akan menenpati posisi pertama.

Tabel 13 Perankingan kelompok dengan menggunakan BORDA

\begin{tabular}{|l|c|c|c|c|c|c|}
\hline Alternatif & DM 1 & DM 2 & Nilai DM 1 & Nilai DM 2 & Nilai & Ranking \\
\hline A1 & 5 & 4 & 2 & 3 & 5 & 4 \\
\hline A2 & 3 & 3 & 4 & 4 & 8 & 3 \\
\hline A3 & 2 & 2 & 5 & 5 & 10 & 2 \\
\hline A4 & 4 & 5 & 3 & 2 & 5 & 4 \\
\hline A5 & 6 & 6 & 1 & 1 & 2 & 6 \\
\hline A6 & 1 & 1 & 6 & 6 & 12 & 1 \\
\hline
\end{tabular}

Ranking pertama ditempati oleh desa wisata jati luwih, sedangkan ranking terakhir di tempati oleh Desa Nyambu.

\section{KESIMPULAN}

Kesimpulan yang diperoleh dari hasil penelitan dan pembahasan pada penelitian ini adalah Model AHP dan BORDA mampu menentukan desa wisata terbaik dengan menggunakan penilaian dari masing-masing DM. Implementasi sistem pendukung keputusan kelompok dalam pemilihan Desa wisata dapat melakukan perubahan data kriteria dan alternatif, sehingga evaluasi perkembangan alternatif desa wisata dapat ditentukan sesuai kebutuhan. Sistem yang 
dikembangkan menghasilkan ranking alternatif desa wisata berdasarkan urutan nilai bobot yang dilakukan oleh Dinas Pariwisata Prov. Bali dan Pemda kabupaten Tabanan.

\section{SARAN}

Hasil penelitian diatas, terdapat beberapa hal yang perlu ditambahkan dan dikembangkan untuk penelitian selajutnya diantaranya, peneliti selanjutnya yaitu dapat menggunakan metode lain dalam mencari bobot dengan menggunakan metode ANP. Analisa pemilihan desa wisata dapat menerapkan kombinasi metode yang lain sehingga dapat dijadikan perbandingan bobot atau ranking yang di hasilkan.

\section{DAFTAR PUSTAKA}

[1] BPSBali, "Perkembangan Pariwisata BALI Juni 2016," 2016.

[2] P. Sugiartawan, R. Pulungan, and A. K. Sari, "Prediction by a Hybrid of Wavelet Transform and Long-Short-Term-Memory Neural Network," Int. J. Adv. Comput. Sci. Appl., vol. 8, no. 2, pp. 326-332, 2017.

[3] T. L. Saaty, "Decision making with the analytic hierarchy process," Int. J. Serv. Sci., vol. 1, no. 1, p. 83, 2008.

[4] M. A. Budhi and R. Wardoyo, "Group Decision Support System Determination Of Best Employee Using Topsis And Borda," IJCCS (Indonesian J. Comput. Cybern. Syst., vol. 11, no. 2, p. 165, 2017.

[5] G. Ogiana, N. Made, A. Esta, D. Wirastuti, and W. G. Ariastina, "Group Decision Support System ( GDSS ) Untuk Evaluasi Penawaran Pekerjaan Konstruksi Menggunakan Metode AHP dan Borda," Teknol. Elektro, vol. 16, no. 3, 2017.

[6] A. Mauko, B. Muslimin, and P. Sugiartawan, "Sistem Pendukung Keputusan Kelompok Dalam Pemilihan Saham Indeks LQ 45 Menggunakan Metode," J. Sist. Inf. dan Komput. Terap. Indones., vol. 1, no. 1, pp. 25-34, 2018.

[7] M. Meng, "The Research and Application of the Risk Evaluation and Management of Information Security Based on AHP Method and PDCA Method," Int. Conf. Inf. Manag. Inov. Manag. Ind. Eng., pp. 379-383, 2013.

[8] T. L. Saaty, "Fundamentals Of Decision Making and Prority Theory With The Analityc Hierarchy Process," vol. 8, 2007.

[9] Suwena, I Ketut, Pengetahuan Dasar Ilmu Pariwisata, Denpasar: Udayana Press, 2010

[10] Prasiasa, Putu Oka, Destinasi pariwisata, berbasis masyarakat, Jakarta : Salemba Empat, 2012.

[11] Zebua, M., Inspirasi Pengembangan Pariwisata daerah, Deepublish, Yogyakarta, 2016

[12] Sastrayuda, Gumelar, "Konsep Pengembangan Kawasan Ekowisata", Yogyakarta, 2010

[13] P. Sugiartawan, I. D. K. Rustina, and R. Saleh Insani, "E-Government Media Informasi Alat Kelengkapan Dewan Provinsi Bali dan Media Diskusi Berbasis Website", jsikti, vol. 1, no. 2, pp. 75-86, Dec. 2018.

[14] P. Sugiartawan, H. Rowa, and N. Hidayat, "Sistem Pendukung Keputusan Kenaikan Jabatan Menggunakan Metode Profile Matching", jsikti, vol. 1, no. 2, pp. 97-108, Dec. 2018.

[15] P. Sugiartawan and S. Hartati, "Group Decision Support System to Selection Tourism Object in Bali Using Analytic Hierarchy Process (AHP) and Copeland Score Model," 2018 Third International Conference on Informatics and Computing (ICIC), Palembang, Indonesia, 2018, pp. 1-6.

[16] D. Dwi Utami Putra and P. Sugiartawan, "Sistem Informasi Geografis Tata Guna Lahan di Kabupaten Sleman", jsikti, vol. 1, no. 3, pp. 175-184, Mar. 2019.

JSIKTI Vol. 2, No. 1, September 2019: $43-52$ 